\title{
Printing of tunics by simulating Anasazi ceramic patterns and their construction
}

Received: 02.03.2017; Accepted: 23.05.2017

See end of the paper for authors' affiliations JAGRITI KAUR GARCHA Department of Apparel and Textile Science, College of Home Science, Punjab Agricultural University, LUDHIANA (PUNJAB) INDIA Email : glorygarcha@yahoo.com
ABSTRACT : For this study, different patterns of Anasazi pottery were collected from various secondary sources. A total of forty Anasazi ceramic patterns were documented through photographs and given code numbers from 1-40. After documentation, thirty ceramic patterns were shortlisted by the panel of 15 judges. These patterns were then used for simulation for developing tunic designs. Different designs of tunics (30) were developed in different silhouettes using basic black and white colour combination of Anasazi ceramic patterns. These designs were developed through computer aided designing (CAD) using Corel Draw X4. While designing tunics, different Anasazi ceramic patterns were simulated, trimmed, adjusted, enlarged, and reduced in size with the help of different tools provided in Corel Draw X4. Thirty designs of tunics were shown to the respondents to get their preferences. On the basis of preferences of the respondents, five top ranked designs of tunics were selected for printing and construction. Printing of selected tunic designs was done through screen and stencil printing techniques depending upon the intricacy of design used. These printed tunics were then constructed using measurements of 36 " size dress form.

KEY WORDS: Anasazi, Tunics, Printing, Construction, Designs, Patterns

- HOW TO CITE THIS PAPER : Garcha, Jagriti Kaur and Saini,Harminder Kaur (2017). Printing of tunics by simulating Anasazi ceramic patterns and their construction. Asian J. Home Sci., 12 (1) : 271-277, DOI: 10.15740/HAS/AJHS/12.1/271-277. 